\title{
METODA WITNESSING UNTUK PENENTUAN KONSTANTA PROSES CNC TURNING PADA MANUFAKTUR KOMPONEN AEROSPACE
}

\author{
Gunawan Refiadi \\ Program Studi Pendidikan Teknik Mesin STKIP Sebelas April, \\ Sumedang \\ email : g4refiadi@gmail.com
}

\begin{abstract}
ABSTRAK
Penelitian ini merupakan hasil pengabdian kepada masyarakat dalam bentuk kontribusi pendampingan pada penyelesaian kasus pengembalian pajak bahan baku impor dari pihak produsen komponen aerospace ke pihak bea cukai. Tujuannya membuktikan bahwa kehilangan berat bahan baku adalah murni karena kegiatan proses produksi. Metodologi yang digunakan adalah witnessing proses CNC Turning melalui dokumentasi bahan baku, proses plan, jenis mesin, proses pemesinan, kontrol kualitas, dan pengelolaan limbah hasil proses yang berjalan untuk 16 sample produk berbasis material logam berbentuk poros pejal. Berdasarkan hasil review teori pemesinan MRP (Metal Removal Process) dan dokumentasi proses diperoleh hasil yang bersesuaian yaitu bahwa kehilangan logam adalah murni akibat proses pembentukan produk dan bukan disebabkan hal yang lain.
\end{abstract}

Kata kunci : aerospace, MRP, CNC Turning, limbah

\section{Pendahuluan}

Perusahaan asing yang ada di Indonesia banyak memakai tenaga anak bangsa Indonesia. Keterampilan mengoperasikan mesin berbasis komputer seperti CNC Turning telah telah diakui dalam memproduksi komponen aerospace mulai dari jenis Airbus 400 hingga Boeing 747. Standar internasional yang ketat sudah pasti telah dipenuhi baik dari sisi bahan baku, prosedur proses, hingga kualitas produk yang dihasilkan.

Pada banyak perusahaan pemesinan yang berorientasi ekspor, bahan baku standar berbasis logam didatangkan dari importir internasional. Begitu pula standar prosedur pelaksanaan proses dengan mudah dikomunikasikan karena bahasa teknik produksinya sama yaitu Non-Conventional $M R P$ (material removal processes). Dengan demikian, jelaslah bahwa standar produk akhir sudah bisa dipastikan mudah dicapai apabila standar bahan dan prosedur proses dilaksanakan dengan pengawasan yang ketat. Artinya, produk yang dihasilkan oleh para operator anak bangsa Indonesia ini bisa dipertanggungjawabkan secara internasional bahkan dunia.

Masalah kemudian timbul ketika ekspor komponen logam yang dihasilkan operator lokal namun berbahan baku impor, berimbas kepada pengembalian pajak impor. Besarnya nilai pengembalian pajak impor ini berkaitan erat dengan tingkat pemakaian bahan logam. Konsep perusahaan asing pada pemakaian bahan baku adalah semakin banyak limbah proses, semakin besar nilai pengembalian pajak impor. Di lain fihak, ada pula pemahaman bahwa limbah proses masih bernilai ekonomis sehingga masih layak dikenai pajak impor.

Untuk menengahi dualisme pemahaman dan perbedaan kepentingan ini, maka ditunjuk tim indepenen untuk melakukan penelitian mengenai karakteristik metoda MRP beserta hubungannya terhadap pemakaian bahan baku. Dari sinilah pelaksanaan pengabdian kepada masyarakat ini mulai dilaksanakan. Berdasarkan hal tersebut, maka penelitian ini ditujukan untuk mendapatkan hubungan atara karakteristik metoda MRP dengan pemakaian bahan baku logam.

\section{Studi Pustaka}

MRP [1] meliputi proses pemesinan, pemotongan, gerinda, dan berbagai proses pembentukan mekanik tanpa menghasilkan geram (chipless) dipilih karena alasan berikut: (1) ketatnya pemenuhan toleransi dimensi dan kekasaran permukaan yang yang 
tidak dapat dicapai oleh proses pengecoran, pembentukan, metalurgi serbuk, dan proses pembentukan lainnya, (2) geometri produk akan terlalu mahal bila diproses dengan cara selain MRP. Pemesinan sendiri adalah pembentukan geram oleh perkakas dan geram adalah limbah logam yang berharga jutaan dolar/tahun [2]. Metal cutting [3]/ pemesinan adalah merubah sebagian benda kerja logam yang tidak diinginkan menjadi bentuk geram (chips) untuk mendapat produk akhir yang geometri, ukuran, dan kehalusan permukaannya sesuai harapan.

Meskipun demikian, MRP memiliki kelemahan, diantaranya terbentuknya geram (chip), laju produksi lambat, kinerja produk dan permukaan kurang baik bila proses tidak dilakukan dengan tepat. Salah satu teknik MRP bisa dilakukan dengan metoda CNC Turning dengan jenis operasinya tampak pada Gambar-1. Karena kontrol gerak mesinnya menggunakan motor dan sensor berbasis komputer, metoda pembentukan logam dengan teknik non-konvensional (CNC Turning) dapat mencapai ketelitian tinggi, sehingga teknik ini sering dipakai untuk memproduksi komponen otomotif, rotating equipment, bahkan komponen pesawat terbang (aerospace).

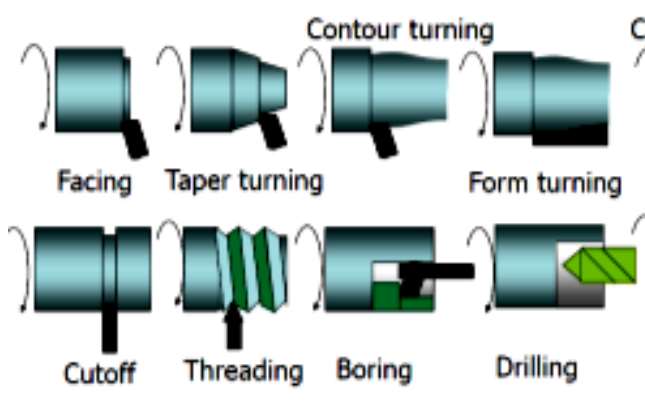

Gambar-1 : Jenis-jenis operasi turning [6]

Produk dengan ketelitian, laju produksi, dan tingkat keterulangan yang tinggi bisa dicapai oleh teknik CNC sehingga dapat memproduksi massal [4]. Lebih dari $90 \%$ produksi komponen logam menggunakan teknik CNC karena pertimbangan kontrol dimensi yang ketat. Di sisi lain, proses pemesinan dipilih karena pertimbangan pembentukan material tidak melibatkan pencairan logam dan temperatur prosesnya tidak tingi, serta tingkat cacat produknya minimum sehingga dianggap lebih ekonomis. Meskipun demikian, teknik ini masih dianggap terlalu banyak menghasilkan limbah.

Penelitian yang dilakukan [5] membuktikan untuk produk yang sama teknik CNC ternyata menghasilkan $76,12 \%$ lebih banyak limbah dibanding metoda metalurgi serbuk/powder metallurgy). Pembuktian ini didasarkan kepada sistem manufaktur yang mempertimbangkan kelestarian lingkungan, efek sosial, dan pencapaian kesejahteraan.

Alur sistem komunikasi perintah CNC tampak pada Gambar-2. Dimana komputer menerima input perintah berupa posisi, kemudian memprosesnya, dan mengeluarkan perintah berupa sinyal gerak. Elemen CNC ada enam yaitu: program, alat penginput program, unit kendali mesin (MCU), sistem gerak, perkakas mesin, dan sistem umpan balik [6].

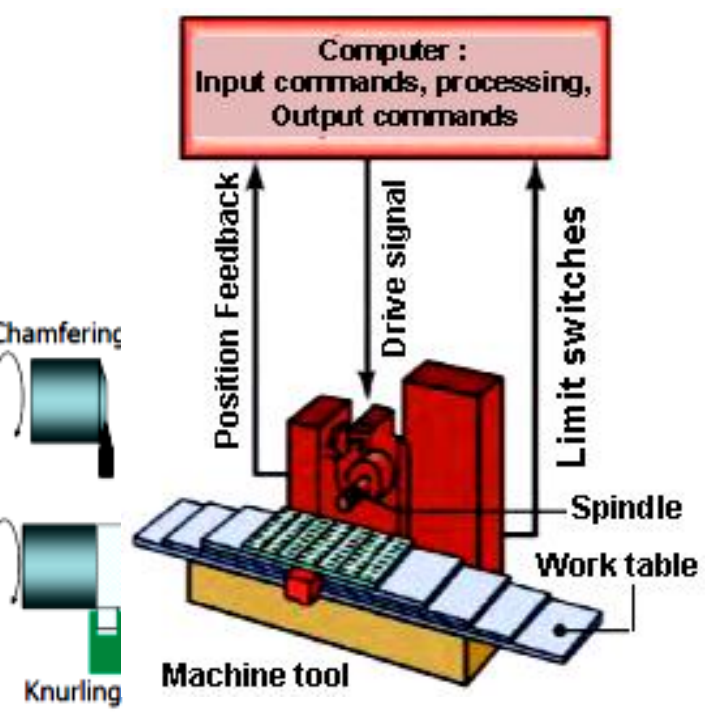

Gambar-2 cara kerja mesin CNC [6]

Pada mesin CNC, program adalah perintah posisi $(\mathrm{x}, \mathrm{y}, \mathrm{z})$, gerak benda kerja atau perkakas, parameter pemesinan (kecepatan, gerak makan, putaran), dan fungsi on/off. MCU adalah mikrokomputer yang menyimpan program dan mengeksekusi perintah untuk dijalankan perkakas mesin (machine tool). Didalamnya terdiri atas unit pemroses data (DPU) dan unit kendali loop (CLU). Software DPU berisi sistem kontrol, kalkulasi algoritma, konverter gerak translasi 
untuk MCU, interpolasi gerak halus, dan edit program apabila ada pergantian atau eror. Sedangkan CLU berisi sirkuit posisi dan loop kendali kecepatan, serta fungsi kontrol spindle on/off. Hasil proses DPU diberikan kepada CLU, sehingga MCU dapat melaksanakan perintah dengan tepat.

Perkakas mesin bisa berbentuk turning, milling, laser, plasma, maupun mesin pengukur koordinat (CMM). Dari Gambar-2 tampak bahwa komputer melakukan input/output perintah program serta memproses umpan balik untuk mengontrol jalannya proses.

Sistem kontrol yang sesuai untuk keperluan gaya penahan gerak benda kerja atau perkakas, seperti pada proses miling dan turning, adalah sistem loop tertutup (Gambar-3). Pada sistem ini kepastian posisi ditentukan oleh alat umpan balik/feedback dan motor servo DC. Sensor umpan balik berupa encoder optic yang terdiri atas sumber cahaya, foto detektor, dan disk yang terdiri atas barisan slot. Encoder ini terhubung ke leadscrew. Ketika ulir berputar, maka slot menyebabkan cahaya tertangkap oleh foto detektor dan dikonversi menjadi pulsa listrik yang selanjutnya dipakai untuk menetapkan posisi dan kecepatan.

\section{Bahan dan Metodologi}

Material objek adalah 16 sampel produk logam yang tengah berjalan proses produksinya (Tabel-1) dan terdiri atas jenis logam dan paduan Aluminium, Stainless steel, Berilium, Berilium-Copper, dan Bronze.

Metodologi witnessing yang dipakai pada studi ini merupakan standard operational procedure (SOP) tim independen yang telah teruji untuk melakukan pembuktian proses/fenomena secara riil. SOP terbukti mampu menyimpulkan secara netral sehingga dapat menegahi dua kepentingan dan atau dua pemahaman dari fihak-fihak yang berbeda interpretasi.

Tim independen melakukan diskusi grup terlebih dahulu dengan divisi manufaktur agar proses witnessing berjalan lancar tanpa mengganggu keberlangsungan proses produksi di shop floor. Setelah alur witnessing disepakati, tim melakukan dokumentasi bahan baku, mesin dan perkakas proses, alat ukur kontrol kualitas, process plan, dan tahapan proses produksi.

Untuk mendapatkan hubungan antara karakteristik metoda MRP dengan bahan baku, maka teknik MRP yang dipilih adalah CNC Turning. Bentuk material dipilih tetap, yaitu bentuk silinder pejal dengan jenis material yang divariasikan. Sedangkan untuk mendapatkan konstanta material, setiap produk divariasikan berdasarkan jenis dan faktor bentuk material.

Data yang diperoleh kemudian dianalisis berdasarkan teori MRP dan aplikasi teknik CNC Turning. Hasil yang diperoleh kemudian dilaporkan kepada pihak-pihak yang berkompeten dalam bentuk presentasi

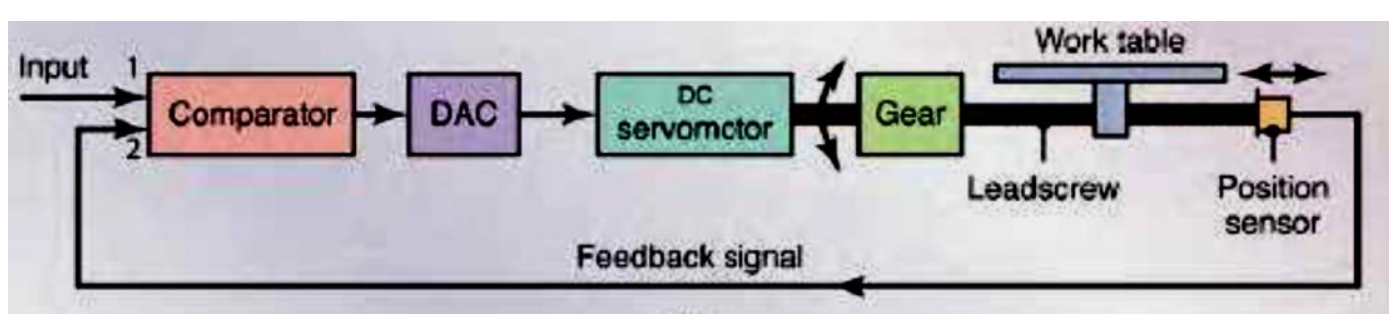

Gambar-3 sistem kontrol loop tertutup yang diaplikasikan pada CNC Turning untuk mengatur gerak mata pahat dan benda kerja melalui mekanisme servo dan sensor posisi [5] 


\section{Data Dan Pembahasan}

Witnessing mendokumentasikan kondisi bulk material (Gambar-4) yang lokasi penyimpanannya bersatu dengan shop floor area. Berdasarkan ilustrasi foto dan data Tabel-1 bentuk dan jenis material bahan baku proses adalah material poros pejal berbasis ferro alloys (stainless steel) dan non-ferro alloys (Berilium, Berilium Copper, Bronze, dan Aluminium).

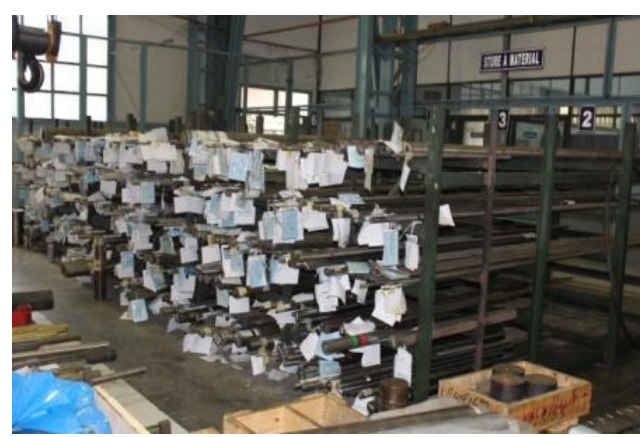

Gambar-4 stok material silinder pejal di area shop floor

Bulk material yang akan dipakai produksi harus dipesan dahulu oleh departemen teknik, kemudian bagian inventori menyiapkan material sesuai dimensi, ukuran, dan bentuk yang diminta. Gambar-5 menujukkan mesin potong logam saat memotong bulk material untuk memenuhi permintaan material dari departemen teknik sesuai process plan. Bulk material ini kemudian dipotong menggunakan gergaji mesin khusus (Gambar-5) sesuai kapasitas machine chamber yang dimiliki oleh setiap mesin CNC Turning.

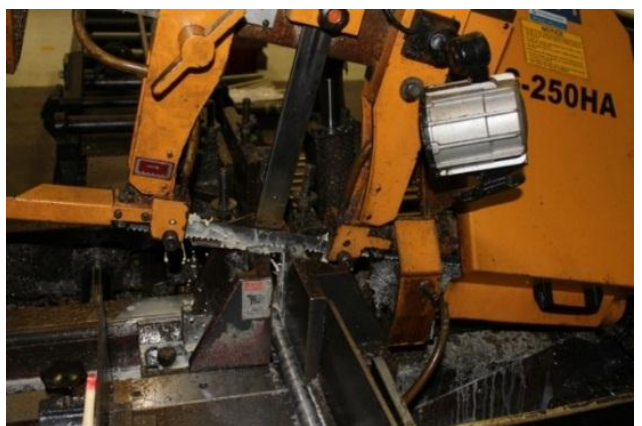

Gambar-5 gergaji khusus untuk pemotongan bulk material sebelum masuk mesin $\mathrm{CNC}$
Tabel-1 memperlihatkan jenis bahan dan nama produk sample yang dilibatkan dalam proses witnessing sesuai hasil diskusi awal dengan divisi manufaktur. Seluruh material berbentuk silinder pejal dengan diameter bervariasi antara $31,75 \mathrm{~mm}$ untuk produk Threaded Ring sampai $120 \mathrm{~mm}$ Flange Hub Long. Panjang produk bervariasi antara 8,520 $\mathrm{mm}$ (Threaded Ring) hingga 452,008 mm (Piston Rod). Proses pemesinan material menjadi produk akhir dilakukan menggunakan jenis mesin CNC Turning dan CNC Turet.

Tabel-1 Identitas witnessing produk komponen logam

\begin{tabular}{|c|c|c|c|c|}
\hline No & $\begin{array}{l}\text { Product } \\
\text { Name }\end{array}$ & $\begin{array}{c}\text { Part } \\
\text { Number }\end{array}$ & $\begin{array}{c}\rho \\
(\mathrm{gr} / \mathrm{cm} 3)\end{array}$ & Matl. \\
\hline 1 & $\begin{array}{c}\text { Spring } \\
\text { Housing }\end{array}$ & $\begin{array}{c}\mathrm{CH} 1741- \\
0059 / \mathrm{B} \\
\end{array}$ & 2.369 & $\mathrm{Al}$ \\
\hline 2 & $\begin{array}{l}\text { Threaded } \\
\text { Ring }\end{array}$ & D59500 & 7.909 & SS \\
\hline 3 & $\begin{array}{l}\text { Heat } \\
\text { Shield }\end{array}$ & $1667-4005$ & 7.909 & SS \\
\hline 4 & $\begin{array}{c}\text { Adaptor } \\
65\end{array}$ & $\begin{array}{c}\text { CH1630- } \\
0065\end{array}$ & 7.909 & SS \\
\hline 5 & Handwind & $\begin{array}{c}\text { CH1878- } \\
1067\end{array}$ & 8.304 & $\mathrm{Be}$ \\
\hline 6 & $\begin{array}{l}\text { Piston } \\
\text { Rod }\end{array}$ & D59473-1 & 7.909 & SS \\
\hline 7 & $\begin{array}{c}\text { Actuator } \\
\text { Body }\end{array}$ & GA63024 & 7.909 & SS \\
\hline 8 & $\begin{array}{c}\text { Bearing } \\
\text { Ring }\end{array}$ & $\begin{array}{c}\text { CH1541- } \\
\text { 0086/F }\end{array}$ & 8.302 & $\begin{array}{l}\mathrm{Be}- \\
\mathrm{Cu}\end{array}$ \\
\hline 9 & $\begin{array}{c}\text { Gimbal } \\
\text { Pivot }\end{array}$ & $\begin{array}{c}\mathrm{CH} 2151- \\
0058 / \mathrm{C}\end{array}$ & 7.909 & SS \\
\hline 10 & $\begin{array}{c}\text { Stop } \\
\text { Piston }\end{array}$ & $1776-4022$ & 2.369 & $\mathrm{Al}$ \\
\hline 11 & $\begin{array}{l}\text { Rod End } \\
\text { Gland }\end{array}$ & $\begin{array}{c}\mathrm{CH} 2039- \\
0074\end{array}$ & 9.003 & $\begin{array}{c}\mathrm{Cu}- \\
\mathrm{Sn}\end{array}$ \\
\hline 12 & $\begin{array}{l}\text { Protection } \\
\text { Cap }\end{array}$ & $\begin{array}{c}\text { CH1544- } \\
0161 / 2\end{array}$ & 7.909 & SS \\
\hline 13 & $\begin{array}{l}\text { B.Splined } \\
\text { Coupling, } \\
\text { F. }\end{array}$ & $\begin{array}{c}\text { CHM833- } \\
2711\end{array}$ & 7.909 & SS \\
\hline 14 & $\begin{array}{l}\text { Cylinder } \\
\text { Housing }\end{array}$ & $\begin{array}{c}\mathrm{CH} 1878- \\
1018\end{array}$ & 8.304 & $\mathrm{Be}$ \\
\hline 15 & BUSH & $\begin{array}{c}\text { CH1542- } \\
0143\end{array}$ & 9.003 & $\begin{array}{c}\mathrm{Cu}- \\
\mathrm{Sn}\end{array}$ \\
\hline 16 & $\begin{array}{c}\text { Flange } \\
\text { Hub Long }\end{array}$ & 800-0103 & 7.909 & SS \\
\hline
\end{tabular}


Untuk melihat tahapan proses yang dilakukan pada 16 jenis produk sampel maka pada Tabel-2 diperlihatkan cuplikan proses

plan untuk pembuatan komponen Spring Housing. Cuplikan ini merupakan rangkuman lembar process plan sesungguhnya yang dijadikan acuan proses produksi di shop floor.

Mesin CNC Turning yang dipakai pada proses witnessing adalah Mazak Naxus 200-II MY (Gambar-6). Mesin ini memiliki kemampuan untuk melakukan proses turning dan milling. Dengan kemampuan ini maka mesin dapat menghemat waktu karena pembuatan program dan setting alat dapat dilakukan secara simultan dalam satu kali jalan.

Tabel-2 spring housing process plan

\begin{tabular}{l|l|l}
\hline No & $\begin{array}{c}\text { Deskrip } \\
\text { si }\end{array}$ & \multicolumn{1}{|c}{ Keterangan } \\
\hline 1 & $\begin{array}{l}\text { Identitas } \\
\text { Produk }\end{array}$ & $\begin{array}{l}\text { Memuat detail nama produk, } \\
\text { spek.material, kode produksi, } \\
\text { Gambar ukuran bahan baku, } \\
\text { urutan proses, mesin proses }\end{array}$ \\
\hline 2 & $\begin{array}{l}\text { Proses } \\
\text { Pemesin } \\
\text { an }\end{array}$ & $\begin{array}{l}\text { Detail alat, jenis mesin, serta } \\
\text { urutan proses pemesinan CNC } \\
\text { Turning }\end{array}$ \\
\hline 3 & $\begin{array}{l}\text { Quality } \\
1\end{array}$ & $\begin{array}{l}\text { Informasi tahapan pengujian } \\
\text { dimensi bentuk dan geometri } \\
\text { spring housing }\end{array}$ \\
\hline 4 & Inspeksi & Pengujian cacat \\
\hline 5 & $\begin{array}{l}\text { Surface } \\
\text { Treatme }\end{array}$ & $\begin{array}{l}\text { Proses perlakuan permukaan } \\
\text { Aluminium (anodising) }\end{array}$ \\
\hline 6 & $\begin{array}{l}\text { Inspeksi } \\
\text { Akhir }\end{array}$ & $\begin{array}{l}\text { Sertifikasi Produk, kemasan, dan } \\
\text { Persiapan ekspor }\end{array}$ \\
\hline
\end{tabular}

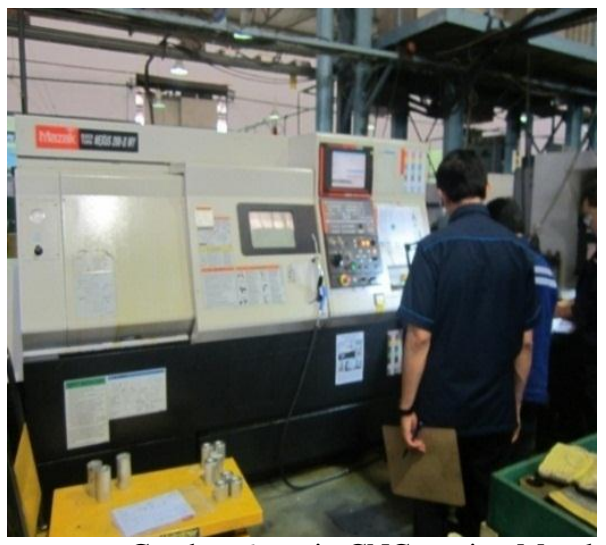

Gambar-6 mesin CNC turning Mazak Naxus 200-II MY

Gambar-7 memperlihatkan salah satu dokumentasi witnessing pada proses turning yang sedang berlangsung di dalam machine chamber Mazak Naxus 200-II MY, yaitu langkah pertama pembentukan komponen spring housing.

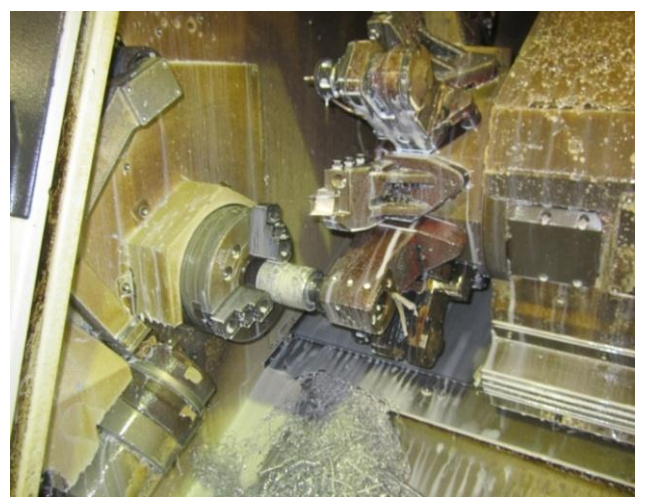

Gambar-7 CNC Turning komponen spring housing

Selanjutnya,

Gambar-8 memperlihatkan dokumentasi perbandingan antara bahan baku Aluminium dan sampel produk lainnya yaitu stop piston yang telah dilakukan penelitiannnya oleh Refiadi [7]. Dari Gambar-8, tampak bahwa transformasi geometric terjadi dari bentuk pejal menjadi bentuk cincin. 
Dari perbedaan geometri, dimensi, dan kekasaran permukaan ini dapat diamati bahwa terdapat sebagian logam yang ada pada material bahan baku memang sengaja dihilangkan untuk dapat mencapai bentuk akhir. Berdasarkan ilustrasi Gambar- 8 dan informasi pada Tabel-3, dapat ditemukan bahwa dari bahan satu silinder bulk tersebut dapat dihasilkan menjadi 7 (tujuh) produk stop piston melalui proses machining menggunakan CNC Turning Mazak Naxus 200II $M Y$.

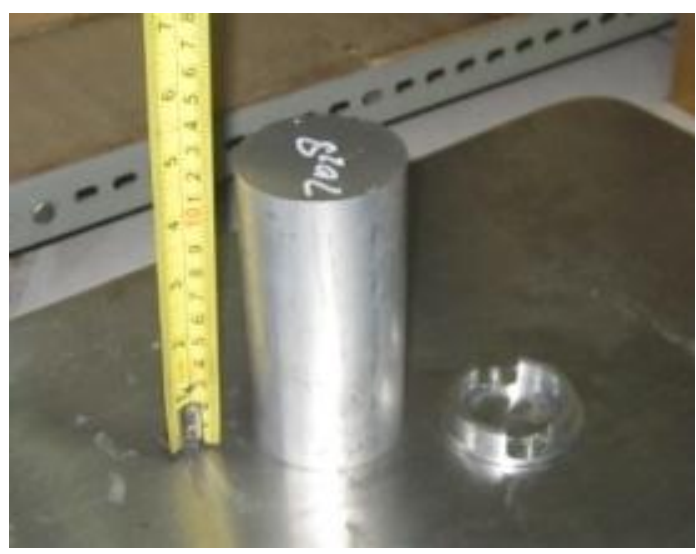

Gambar-8 perbandingan bentuk antara bahan (silinder pejal) dan produk stop piston (ring) sebelum proses dan sesudah proses MRP CNC Turning

Data limbah yang terbuang dalam bentuk geram maupun panjang diperlihatkan pada Tabel-3. Tampak bahwa kehilangan berat sangat besar dari setiap produk. Hal ini terjadi karena hampir seluruh produk ditransformasi dari bahan baku berbentuk pejal (massive) menjadi produk berbentuk selongsong (hollow) atau pipa. Namun demikian, apabila dilihat dari perubahan panjang, akan ditemukan bahwa waste yang ditimbulkan jauh lebih kecil. Hal ini terjadi karena pemotongan bahan dari bulk dilakukan seefisien mungkin dengan jalan mengetahui secara pasti berapa panjang yang diperlukan untuk positioning pada chuk mesin.

Sebagai contoh dapat dilihat data (Tabel-3). Dari hasil pengukuran stop piston diperoleh data awal panjang bahan baku 92,046 mm dan panjang akhir produk 11,44 $\mathrm{mm}$ atau $1,144 \mathrm{~cm}$. Dari Tabel dilihat terdapat 7 (tujuh) unit stop piston, berarti total panjang produk stop piston adalah 80,08 mm sehingga total limbah stop piston dalam bentuk panjang hanya $11,965 \mathrm{~mm}$ atau 1,2 cm. Limbah sepanjang ini tidak mungkin dibuat produk yang lain karena tidak bisa dicengkram pada chuck mesin CNC. Bentuk waste inilah (Gambar-9) yang bisa dipermasalahkan apabila tidak ada laporan dari fihak manufaktur kepada pihak beacukai.

Dari Tabel-3 dapat diamati prosentase limbah proses dalam bentuk kehilangan berat dan kehilangan panjang. Prosentase maksimal limbah dalam bentuk kehilangan panjang bahan hanya $18,56 \%$, yaitu pada produk spring housing dan minimal sebesar $0,66 \%$ piston rod. Sedangkan persentase ratarata limbah panjang bahan (waste length) dari keenambelas produk tersebut adalah 7,66\%. Jumlah ini sangat kecil dan menunjukkan efisiensi pemakaian bahan sangat tinggi.

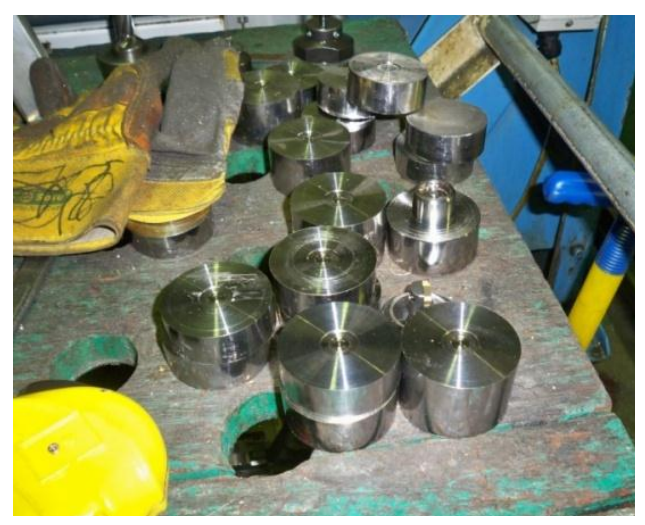

Gambar-9 limbah material proses CNC Turning

Tabel-3 perhitungan limbah produk ( $\%$ panjang awal)

\begin{tabular}{|c|c|c|c|c|c|}
\hline No & Product Name & $\begin{array}{l}\text { Qty } \\
\text { (pes) }\end{array}$ & $\begin{array}{c}\text { Part legth } \\
(\mathrm{mm})\end{array}$ & $\begin{array}{c}\text { Waste } \\
\text { legth } \\
(\%)\end{array}$ & $\begin{array}{c}\text { Waste } \\
\text { weight } \\
(\%)\end{array}$ \\
\hline 1 & Spring Housing & 1 & 136,820 & 18,56 & 82,20 \\
\hline 2 & Threaded Ring & 30 & 8,520 & 3,26 & 88,00 \\
\hline 3 & Heat Shield & 72 & 19,510 & 1,37 & 92,80 \\
\hline 4 & Adaptor 65 & 15 & 38,770 & 6,27 & 82,20 \\
\hline 5 & Handwind & 10 & 38,050 & 9,13 & 88,90 \\
\hline 6 & Piston Rod & 1 & 452,008 & 0,66 & 83,50 \\
\hline 7 & Actuator Body & 1 & 442,327 & 1,71 & 92,80 \\
\hline 8 & Bearing Ring & 20 & 10,08 & 4,80 & 89,20 \\
\hline 9 & Gimbal Pivot & 20 & 16,96 & 4,70 & 93,60 \\
\hline 10 & Stop Piston & 7 & 11,440 & 13,0 & 83,80 \\
\hline
\end{tabular}




\begin{tabular}{c|c|c|c|c|c}
11 & Rod End Gland & 10 & 41,400 & 9,1 & 75,30 \\
\hline 12 & Protection Cap & 6 & 48,170 & 14,5 & 74,80 \\
\hline 13 & $\begin{array}{c}\text {..Splined Coupling, } \\
\text { F. }\end{array}$ & 6 & 47,800 & 14,4 & 91,30 \\
\hline 14 & Cylinder Housing & 1 & 135,600 & 3,2 & 90,00 \\
\hline 15 & BUSH & 20 & 7,83 & 4,9 & 92,80 \\
\hline 16 & Flange Hub Long & 1 & 73,46 & 13,1 & 89,80 \\
\hline
\end{tabular}

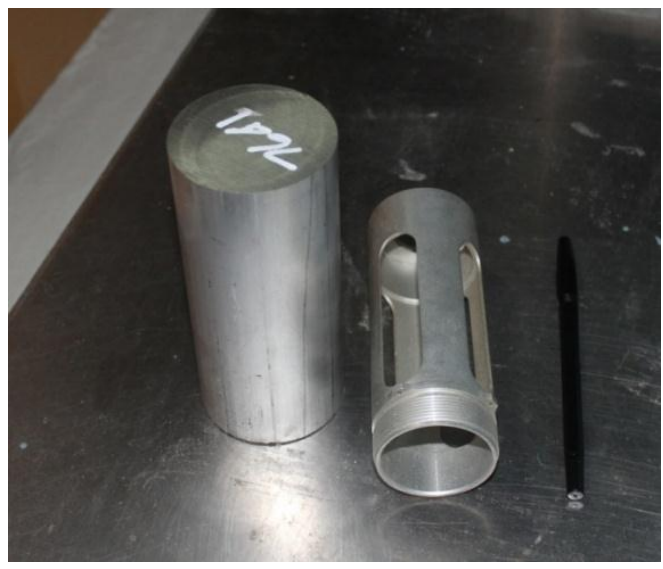

Pada Gambar-10 dapat dilihat bagaimana produk spring housing dibentuk dengan membuang banyak material pada arah aksial dan arah radial sehingga menghasilkan bentuk akhir produk mirip selongsong berlubang. Transformasi bentuk ini telah menghilangkan berat sebesar $82,2 \%$. Di lain fihak, hasil pengukuran produk di arah lateral (Gambar-10) ditemukan bahwa kehilangan material hanya sekitar $18,56 \%$ atau sekitar 2,6 cm saja.

Kehilangan berat material yang besar terjadi pula pada sampel produk lainnya yaitu actuator body (Gambar-11). Data hasil penimbangan berat bahan baku untuk produk ini (Gambar-11a) adalah 25,365 kg ketika menjadi produk (Gambar-11b) data penimbangan berat hanya $1,815 \mathrm{~kg}$ atau terjadi pengurangan berat sebesar $92,8 \%$. Hal ini terjadi karena metoda MRP dengan teknik CNC Turning telah menghilangkan bagian logam yang tidak diperlukan pada arah aksial dari bahan baku yang berbentuk silinder pejal sehingga menjadi produk akhir yang hampir berbentuk mirip pipa (Gambar-11c). Sementara itu, kehilangan panjang pada material actuator body hanya sebesar $1,71 \%$ atau sepanjang $0,7 \mathrm{~cm}$. Sekali lagi, dari sisi kehilangan panjang, pemakaian bahan sudah sangat efisien. Akan tetapi kehilangan berat yang terjadi sangat besar. Inilah konsekwensi logis dari proses MRP, melalui metal cutting CNC Turning dimana deformasi geser terpusat terjadi pada benda kerja secara langsung di ujung mata pahat potong [8].

Gambar-11c memperlihatkan sebagian profil penampang melintang produk actuator body yang pada bagian aksialnya kosong atau membentuk hollow cylinder. Selain itu, bagian luar produk dicapai dengan penghilangan material pula. Gambar-10c memperjelas bukti mengapa kehilangan berat dari bahan ke produk actuator body terjadi dengan prosentase yang besar. Hal ini dapat diuji secara praktis [8] melalui perghitungan tebal geram (pers. (1)) yang dihasilkan dengan cara mengukur panjang dan menimbang berat geram. 


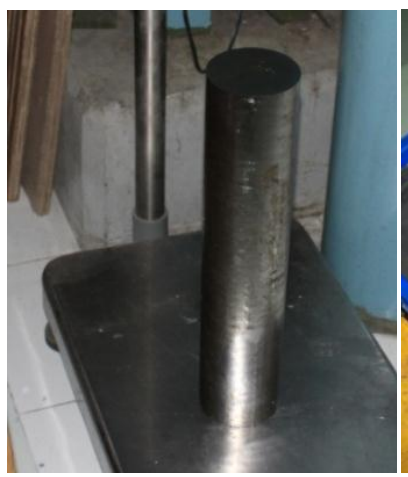

(a)

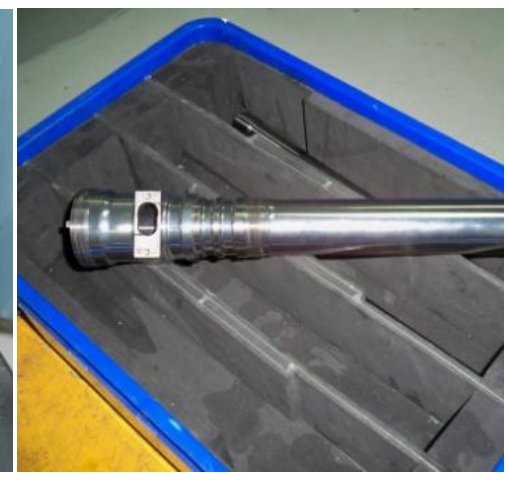

(b)

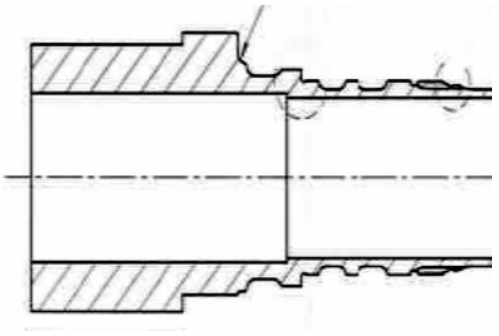

(c)

Gambar-11 a) penimbangan bahan baku Actuator Body $(25,365 \mathrm{~kg})$, b) bentuk produk actuator body (berat akhir $1,815 \mathrm{~kg}$ ). Limbah berat arah aksial 92,8\% dan arah lateral hanya 1,71\%, c) Gambar potongan penampang melintang produk yang menyerupai berbentuk pipa

$$
t_{C}=\frac{W}{\rho t L}
$$
$(\mathrm{mm})$.

dimana, $\rho=$ densitas bahan, $t=$ feed

Berdasarkan detail spek teknis hasil witnessing, permukaan luar actuator body harus memiliki harga 1,6 $\mathrm{R}_{\mathrm{a}}$ (kelas halus/fine) sedangkan bagian internalnya $0,2 \mathrm{R}_{\mathrm{a}}$ (kelas kilap/polish) masing-masing kondisi ini diperoleh melalui teknik grinding dan honing. Pengukuran kekasaran dapat dilakukan menggunakan instrument tipe kontak maupun non-kontak. Kekasaran permukaan (surface roughness) terdiri atas ketidakteraturan dalam textur permukaan akibat aksi inheren proses produksi [9]. Harga pengukuran berupa harga arithmetic average, $R_{a}$. Kekasaran permukaan berkaitan erat dengan akurasi atau toleransi produk. Semakin kecil harga $R_{a}$ akan semakin ketat toleransi dan semakin mahal biaya produksinya karena memerlukan skill, alat, dan teknik pengukuran yang lebih spesifik.

Dari beberapa contoh produk yang dibahas di atas, dapat diketahui bahwa memang metoda pembentukan logam MRP (Metal Removal Processes) dengan teknik CNC Turning selalu menghasilkan pembuangan bagian material yang tidak diperlukan agar mencapai bentuk produk yang diinginkan. Hal ini sesuai dengan definisi metal cutting [3]. Artinya, pertama bahwa metoda MRP selalu menghasilkan limbah proses berupa logam yang diakibatkan oleh aksi pemotongan logam oleh pahat potong (cutting tools). Kedua, konsekwensi logis dari akibat pertama tadi menjadikan produk hasil MRP akan memiliki berat lebih rendah daripada berat material awal atau bahan bakunya.

Temuan di atas telah dapat menjawab pertanyaan mengapa terjadi kehilangan material akibat proses pembentukan logam metoda MRP. Pertanyaan selanjutnya, bagaimanakah menjembatani perbedaan persepsi pengertian limbah antara basis berat dan basis panjang ?. Jawaban dari pertanyaan tersebut bisa diberikan apabila setiap material yang dipakai untuk menghasilkan produk CNC Turning, memiliki konstanta material, $\boldsymbol{K}$. Artinya, kehilangan berat pada arah aksial bisa dikompensasi berupa kehilangan luas penampang. Dengan kata lain kehilangan berat yang dihitung berdasarkan kehilangan volume akan menjadi sama acuannya ketika kehilangan berat dikonversi dalam bentuk satuan panjang atau $\mathrm{Kg} / \mathrm{m}$.

Untuk mendapatkan harga $\boldsymbol{K}$, maka dilakukan perhitungan sederhana berdasarkan satuan densitas, $\rho$. Satuan densitas adalah $\mathrm{kg} / \mathrm{m}^{3}$. Sedangkan kehilangan berat arah aksial mewakili luas penampang, $\boldsymbol{A}$ yang tidak lain satuannya adalah $\mathrm{m}^{2}$. Dengan demikian apabila satuan $\boldsymbol{K}$ adalah $\mathrm{Kg} / \mathrm{m}$, maka dapat dirumuskan bahwa : 


$$
\rho=\frac{K}{A}=\frac{K g / m}{m^{2}}=K g / m^{3}
$$

Atau dengan kata lain, konstanta material $\boldsymbol{K}$ adalah hasil kali antara densitas material $\rho$ dengan luas penampang bahan baku berbentuk silinder, $\boldsymbol{A}$.

$$
\begin{aligned}
K=\rho \cdot A & =\rho \cdot \frac{\pi}{4} D^{2} \\
& =0,785 \cdot \rho \cdot D^{2}
\end{aligned}
$$

Persamaan (3) di atas memperlihatkan bahwa harga konstanta proses CNC Turning dipengaruhi oleh jenis material dan faktor bentuk material. Dalam hal ini, jenis material diwakili oleh karakteristik fisiknya berupa berat jenis atau densitas sedangkan faktor bentuk material diwakili oleh diameter silinder, $\boldsymbol{D}$. Hasil perhitungan dari keenambelas produk yang dilakukan witnessing, memberikan harga $\boldsymbol{K}$ (Tabel-4) yang bervariasi sesuai jenis material dan diameternya.

Tabel -4 : Variasi harga $\boldsymbol{K}$ berdasarkan fungsi sifat fisik dan faktor bentuk material

\begin{tabular}{c|l|c|c|c|c}
\hline No & Product Name & $\begin{array}{c}\rho \\
\mathrm{gr} / \mathrm{cm}^{3}\end{array}$ & $\begin{array}{c}\mathrm{K} \\
\mathrm{kg} / \mathrm{m}\end{array}$ & $\begin{array}{c}\Phi \\
(\mathrm{mm})\end{array}$ & Mat' \\
\hline 1 & Spring Housing & 2,369 & 7,500 & 63,5 & $\mathrm{Al}$ \\
\hline 2 & Threaded Ring & 7,769 & 6,148 & 31,75 & $\mathrm{SS}$ \\
\hline 3 & Heat Shield & 7,909 & 20,279 & 57,15 & $\mathrm{SS}$ \\
\hline 4 & Adaptor 65 & 8,252 & 21,158 & 65 & $\mathrm{SS}$ \\
\hline 5 & Handwind & 8,304 & 12,879 & 44,45 & $\mathrm{Be}$ \\
\hline 6 & Piston Rod & 7,772 & 8,856 & 38,1 & $\mathrm{SS}$ \\
\hline 7 & Actuator Body & 8,055 & 57,064 & 95,0 & $\mathrm{SS}$ \\
\hline 8 & Bearing Ring & 8,302 & 12,876 & 44,45 & $\mathrm{Be}-\mathrm{Cu}$ \\
\hline 9 & Gimbal Pivot & 7,793 & 17,825 & 53,98 & $\mathrm{SS}$ \\
\hline 10 & Stop Piston & 2,738 & 8,668 & 63,5 & $\mathrm{Al}$ \\
\hline 11 & Rod End Gland & 6,703 & 10,396 & 44,45 & $\mathrm{Cu}-\mathrm{Sn}$ \\
\hline 12 & Protection Cap & 2,837 & 2,245 & 31,75 & $\mathrm{SS}$ \\
\hline 13 & $\begin{array}{l}\text { B.Splined } \\
\text { Coupling, F. }\end{array}$ & 7,761 & 17,752 & 53,98 & $\mathrm{SS}$ \\
\hline 14 & $\begin{array}{l}\text { Cylinder } \\
\text { Housing }\end{array}$ & 7,906 & 52,607 & 92,07 & $\mathrm{Be}$ \\
\hline
\end{tabular}

\begin{tabular}{c|l|c|c|c|c}
15 & BUSH & 9,003 & 10,259 & 38,1 & $\mathrm{Cu}-\mathrm{Sn}$ \\
\hline 16 & $\begin{array}{l}\text { Flange Hub } \\
\text { Long }\end{array}$ & 7,914 & 89,455 & 20 & SS \\
\hline
\end{tabular}

Harga K pada Tabel-4 masih konstanta material dan belum dapat mengakomodasi kehilangan logam akibat proses CNC Turning. Oleh karena itu, perlu dicari harga konstanta proses yang dapat mewakili kehilangan logam akibat proses pembentukan. Tetapi karena definisi limbah MRP jika dilihat berdasarkan Gambar-11 adalah keluaran logam dari bahan baku yang sudah tidak bisa dipakai menghasilkan produk sejenis, maka konstanta proses harus ditentukan bukan berdasarkan kehilangan berat bahan baku. Konstanta proses harus ditentukan berdasarkan jenis dan tahapan proses yang dilalui oleh bahan baku hingga akhirnya menjadi produk dengan nilai tambah yang tinggi. Artinya konstanta proses memiliki hubungan erat dengan harga jual produk.
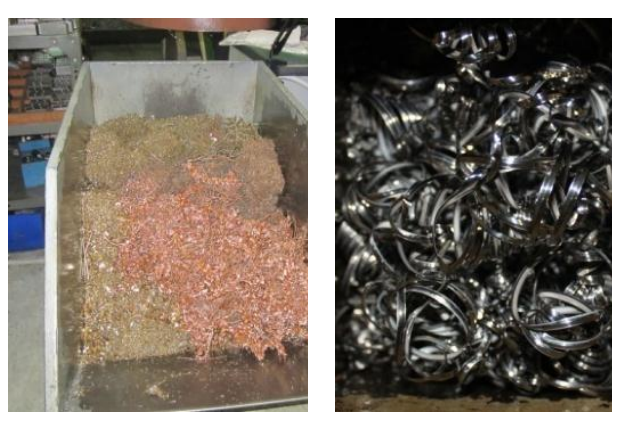

Gambar-11 bentuk (chip) yang merupakan limbah hasil proses CNC Turning

Bentuk hubungan antara konstanta dengan harga jual bisa linear, parabolik atau hyperbolik. Untuk mendapatkan harga kuantitatif dari konstanta proses maka diperlukan penelitian lanjutan yang mempertimbangkan seluruh aspek produksi CNC Turning. Misalnya pertimbangan harga jam mesin, umur pahat, metoda perhitungan minimum cost, dan lain-lain. 


\section{KESIMPULAN}

Proses witnessing telah dilakukan terhadap 16 sample produk dari berbagai jenis logam paduan ferro dan non-ferro melalui proses CNC Turning, yaitu salah satu teknik MRP, yang merupakan keluarga metal cutting. Sesuai dengan definisi metal cutting seluruh produk memperlihatkan kehilangan berat yang signifikan 74,8\% 93,6\% karena transformasi material dari bentuk silinder pejal menjadi bentuk mirip pipa atau selongsong berlubang. Kehilangan berat tersebut adalah mutlak akibat proses pembentukan logam dengan metoda MRP dan bukan merupakan manipulatif untuk mendapatkan keuntungan secara tidak wajar.

\section{SARAN}

Untuk mendapatkan konstanta proses secara kuantitatif dan model matematis yang mengkorelasikan antara konstanta proses dengan harga jual produk, perlu dilakukan penelitian lebih lanjut yang berbasis software.

\section{UCAPAN TERIMA KASIH}

Kepada Ketua STKIP Sebelas April Sumedang diucapakan terima kasih atas perkenannya memberikan surat tugas untuk pelaksanaan PKM ini. Kepada Direktur Utama PT. Goodrich - Pindad JV Indonesia, atas izin pelaksanaan witnessing dan kepada Direktur PT.Sucofindo Indonesia atas kepercayaan yang diberikan untuk dapat bergabung dan bersinergi dalam kebersamaan tim witnessing

\section{DAFTAR PUSTAKA}

[1] Madsen., et al., "Material Removal Processes and Machine Tools," in Manufacturing Processes, Illinois, USA, Institute of Illinois, 2003, pp. 45-76.

[2] J. Colton., "Manufacturing Processes \& Systems," Georgia Institute of Technology, Georgia, 2009.
[3] D. Garmo, Materials and Processes in Manufacturing, 12 th Ed., New York: MacMillan Publishing Company, 2007.

[4] ASM, Machining Handbook Vol.16 11th Edition, Ohio: ASM International, 2005.

[5] Jayachandran, et al., "The design of a sustainable manufacturing system: A case study of its importance to product variety manufacturing," Conventry University, Conventry, UK, 2006.

[6] Akar., B et al., "Computer Numerical Control (CNC)," Hacettepe University, Islamabad, Turkey, 2010.

[7] Refiadi. G., "Pembuatan Komponen Aerospace Al 6082 - T6511 Dengan Metode One Stop Machining," Jurnal Teknologi Bahan dan Barang Teknik, ISSN 2089-4767, vol. 4, no. 2, pp. 13-20, 2014.

[8] J. Black, "Mechanics of Chip Formation," in ASM Machining Handbook Vol. 11, Ohio, ASM International Publisher, 2007, pp. 1828.

[9] Koster. E., "Surface Finish and Surface Integration," in ASM Machining Hanbook, Vol. 11, Ohio, ASM International Publisher, 2007, pp. 43-84.

[10] M. Bibby, Principles of Metal Manufacturing Processes, Canada : Carleton University, 2006. 